J. Lake Sci. (湖泊科学), 2020, 32(4): 1060-1075

DOI 10. 18307/2020. 0415

(c) 2020 by Journal of Lake Sciences

\title{
富营养深水水库底栖动物群落与浮游生物相关性分析
}

\author{
池仕运 ${ }^{1}$, 韦翠珍 ${ }^{2}$, 胡 俊 $^{1}$, 王 瑞 $^{1}$, 周连 凤 ${ }^{1}$, 胡菊香 ${ }^{1 * *}$ \\ ( 1 : 水利部中国科学院水工程生态研究所,水利部水工程生态效应与生态修复重点实验室,武汉 430079) \\ (2:淮河流域水资源保护局淮河水资源保护科学研究所,蚌埠 233001)
}

\begin{abstract}
摘 要: 底栖动物和浮游生物通过食物网发生复杂的交互作用, 是水库生态系统物质循环的重要组分. 南湾水库和汤浦 水库均为存在富营养化现象的深水水库,具有较长时间的水温分层期. 本文选取这两座供水水库为对象, 比较其水体营 养状态、底栖动物的群落结构、现存量和多样性. 通过群落状态指数 (IICS) 定量评估底栖动物群落状态, 并采用 PLS 模 型、Spearman 秩相关以及回归图探讨浮游生物各类群密度与 IICS 的关系. 研究结果显示, 南湾水库富营养程度高于汤浦 水库, 寡毛类在南湾水库占据优势地位, 摇蚊类在汤浦水库数量上占优. 南湾水库以收集者为主, 其数量占比远高于汤浦 水库. 深水水库通常存在较强的热分层, 富营养化会加重水库底部的缺氧或厌氧状态, 导致底栖动物遭受周期性的缺氧 扰动, 影响种类多样性和现存量, 改变浮游生物类群与底栖动物群落的相关性, 因此底栖动物群落与浮游生物的相关性 能够提供判断水库富营养化程度的重要信号,进而为水库管理方提供更多有价值的参考信息.
\end{abstract}

关键词: 富营养化;水温分层; 偏最小二乘法; 群落状态指数;南湾水库;汤浦水库;底栖动物; 浮游生物

\section{Correlation between macroinvertebrates and plankton in two deep eutrophic reservoirs *}

CHI Shiyun ${ }^{1}$, WEI Cuizhen ${ }^{2}$, HU Jun ${ }^{1}$, WANG Rui ${ }^{1}$, ZHOU Lianfeng ${ }^{1}$ \& HU Juxiang ${ }^{1 * *}$

(1: Key Laboratory of Ecological Impacts of Hydraulic-Projects and Restoration of Aquatic Ecosystem of Ministry of Water Resources, Institute of Hydroecology, Ministry of Water Resources and Chinese Academy of Sciences, Wuhan 430079, P.R. China)

(2: Institute of Huai River Water Resources Protection, Bengbu 233001, P.R. China)

\begin{abstract}
In reservoir ecosystems, both macroinvertebrates and plankton play an important role in the matter cycling by interactions in food webs. Nanwan Reservoir and Tangpu Reservoir are deep reservoirs with eutrophication and long-term thermal stratification. In this study, these two reservoirs for drinking water supply were investigated to compare their trophic status, macroinvertebrate community structure, stranding crops and biodiversity. The macroinvertebrate communities were quantitatively assessed by Integral index of communities state (IICS) index, and the relationship between the density of plankton and IICS was explored by a PLS model, Spearman rank correlation and regression charts. The results showed that the trophic state index of Nanwan Reservoir was higher than that of Tangpu Reservoir, oligochaetes dominated in Nanwan Reservoir while chironomids did in Tangpu Reservoir. The collectors dominated in Nanwan Reservoir, where their proportion was much higher than Tangpu Reservoir. In deep reservoirs with thermal stratification, eutrophication aggravated the anoxic or anaerobic status at the reservoir bottom, resulting in the periodic anoxic disturbance to macroinvertebrates and reduced standing crops and biodiversity. The relationship between plankton and macroinvertebrate community shifting from positive correlation to negative one was related to the aggravation of reservoir eutrophication. The deterioration of the benthic habitat environment caused by the intensification of eutrophication and the food shortage caused by plankton's avoidance of unfavorable environment were the fundamental reasons for the sustained decline of macroinvertebrate population. Therefore, the reservoir eutrophication can be detected by exploring the relationship between macroinvertebrate and plankton community, for the aim of providing more valuable reference information to reservoir management.
\end{abstract}

Keywords: Eutrophication; thermal stratification; PLS; IICS; Nanwan Reservoir; Tangpu Reservoir; macroinvertebrates; plankton

* 2019-05-10 收稿; 2019-11-17 收修改稿.

国家自然科学基金项目 (51779158,51279112,51409178) 和国家重点研发计划项目(2017YFC0405303) 联合资助.

** 通信作者; E-mail: hujuxiang2005@163.com. 
我国水库数量众多,其在国民经济建设中发挥了举足轻重的作用. 随着社会和经济的高度发展以及人 为活动的加剧, 污染导致河流和湖泊供水功能弱化, 水库成为了主要的替代供水水源, 这也导致人们对水库 生态环境的关注度逐渐提高 ${ }^{[1]}$. 富营养化和藻类水华已成为当前水库生态环境的重要威胁, 导致部分水库 供水功能的丧失. 不同于天然湖泊, 由于人类的高强度利用, 水库水环境条件会发生快速波动, 从而对生物 群落形成选择压力, $r$-对策者类型的生物由于个体小, 生活周期短, 能够适应这种选择压力, 通常在水库生物 群落中占据主导地位, 如浮游生物 (浮游植物、原生动物、轮虫和浮游甲壳动物) 和底栖动物中的小型种类如 寡毛类和摇蚊类水生昆虫 ${ }^{[2]}$, 而体型较大的底栖动物如螺贝类则在水库中多不常见.

热分层是深水水库的重要湖沼学特性,多发生于气温较高的夏秋季以及湖库的深水区. 湖库表层水体 浮游植物光合作用产生的氧气是水体溶解氧的重要补充来源, 但温跃层的存在阻碍了溶解氧的垂向传递. 在热分层期间, 存在富营养化现象的湖库中较高浓度的氮磷水平会促进水体中浮游生物的大量繁殖,进而 恶化水质, 浮游生物大量死亡后沉于库底的分解活动以及沉积物的耗氧作用会进一步消耗库底溶解氧, 并 产生大量的硫化氢, 导致库底常常处于缺氧或厌氧状态, 利于厌氧微生物的活动, 但对底栖动物的生长繁殖 却极为不利, 即使较为耐受低氧的种类也不能长期生存. 随着气温的下降, 多数湖库的热分层现象会逐渐消 失, 水体在冬春季处于完全混合状态, 底部的溶解氧水平得以提高, 进而底栖动物的生存环境得到暂时改 善 ${ }^{[3-5]}$. 总之, 存在热分层现象且处于富营养化进程中的湖库中的底栖动物会遭受周期性的缺氧扰动, 其种 群规模和生物多样性必然受到一定程度的影响.

在水库食物网中, 浮游生物和底栖动物是鱼类的主要饵料. 浮游植物是重要的初级生产者, 浮游动物和 底栖动物则是重要的次级生产者. 浮游生物和底栖动物在水库分别占据着不同的生态位, 对压力的响应选 择不同的对策, 通过食物网发生复杂的交互作用, 在生态系统物质循环中发挥重要作用 ${ }^{[6-9]}$. 研究表明, 藻型 湖泊中的底栖动物类群的主要食物来源于浮游生物类群 ${ }^{[10-13]}$, 其比重可以占到整个湖沼次级生产力的 $42 \%^{[14-15]}$, 其群落结构状态对维系湖沼生态系统的正常运转至关重要. 自 $1980 \mathrm{~s}$ 以来, 由于大力发展水库渔 业的需要, 作为鱼类的主要㙁料来源, 水库中浮游生物和底栖动物资源量的调查引起人们的重视, 相关调查 资料较多, 但底栖动物和浮游生物的相互关系却很少引起关注, 尽管这些类群在水库生态系统食物网的构 建中发挥着不可替代的作用 ${ }^{[16-18]}$.

南湾水库是一座兴建于 $1950 \mathrm{~s}$ 成库 60 余年的老水库, 具有供水、灌溉、防洪、发电、养殖、旅游等多种功能. 该水库 2000- 2009 年 10 年间,除 2006 年和 2007 年处于轻度富营养化外,其余年份均处于中度富营养化水 平,水温较高的月份深水区存在水温分层现象 ${ }^{[19-20]}$. 汤浦水库是一座以供水为主兼防洪和改善水环境综合利 用的水库,兴建于 2001 年, 2002-2005 年的监测表明水库处于中度富营养化水平 ${ }^{[21]}$, 自 4 月后大部分时间存 在较为明显的热分层现象. 近年来, 公众对水环境质量要求越来越高, 作为城市首选供水水源地的水库的富营 养化和藻类水华问题也成为当政者和民众关注的焦点 ${ }^{[21]}$. 本文选取以上两座存在富营养化现象以供水为主的 深水水库作为调查对象, 定量描述底栖动物群落状态及其与浮游生物的相互关系, 探讨其相互关系与富营养 化程度的耦合性,从而揭示富营养化对存在水温分层现象的水库生态系统的影响效应.

\section{1 材料与方法}

\section{1 研究区域}

本文选取的两座深水水库均存在富营养化和热分层现象, 虽然地理位置相距较远, 但均处于北亚热带 区域, 为典型的季风气候区, 四季分明, 降雨充沛, 年均降雨量 $1000 \mathrm{~mm}$ 以上, 且均为大型丘陵性水库, 水力 滞留时间较长,水体交换系数较低, 在生态意义上具有较多的共性.

南湾水库 $\left(31^{\circ} 50^{\prime} \sim 32^{\circ} 10^{\prime} \mathrm{N}, 113^{\circ} 56^{\prime} \sim 114^{\circ} 32^{\prime} \mathrm{E}\right)$ 位于河南省信阳市, 属于淮河支流浉河流域, 所在流域 属于亚热带向暖温带过渡的季风气候区, 多年降雨量平均为 $1226.2 \mathrm{~mm}$, 多集中在 5-9 月,占全年降雨量的 $70 \%$. 南湾水库有董家河、五道河、小浉河、飞沙河和谭家河等几条汇水河流 ${ }^{[22]}$. 水库兴利库容 $6.7 \times 10^{8} \mathrm{~m}^{3}$, 集雨区面积 $1100 \mathrm{~km}^{2}$, 最大水面面积 $130.7 \mathrm{~km}^{2}$, 正常水面面积 $77.65 \mathrm{~km}^{2}$, 水库补给系数 (水库集雨区面积与 水库最大面积之比) 为 8.42 . 平均水深 $17.4 \mathrm{~m}$, 最深处达 $38 \mathrm{~m}$, 水体交换系数为 0.95 , 为信阳市的主要供水水 源地 ${ }^{[23-25]}$. 
汤浦水库 $\left(29^{\circ} 38^{\prime} \sim 29^{\circ} 54^{\prime} \mathrm{N}, 120^{\circ} 30^{\prime} \sim 120^{\circ} 45^{\prime} \mathrm{E}\right)$ 位于浙江省绍兴市, 属于曹娥江支流小舜江流域, 水库 地处亚热带季风区, 多年平均降水量 $1564.4 \mathrm{~mm}$, 水库内降雨月均分配极不均匀, 3-8 月降雨量约占全年降 水量的 $85 \%$ 以上. 水库水系由南溪、北溪、王化溪与万宝溪四大支流组成, 其中南溪、北溪在库前合流成双江 溪, 其人库流量占水库总径流的比例分别为双江溪 $75.4 \%$ 、王化溪 $13.3 \%$ 、万宝溪 $4.5 \%^{[26]}$. 水库正常蓄水库 容 $1.8513 \times 10^{8} \mathrm{~m}^{3}$, 集雨面积 $460 \mathrm{~km}^{2}$, 最大水面面积 $15.93 \mathrm{~km}^{2}$, 正常水面面积 $14.13 \mathrm{~km}^{2}$, 水库补给系数 (水 库集雨区面积与水库最大面积之比) 为 28.88 . 平均水深达 $20 \mathrm{~m}$, 最深处可达 $30 \mathrm{~m}$ 以上, 水体交换系数为 1.38. 是虞绍平原重要的饮用水源 ${ }^{[21,26]}$.

\section{2 数据收集与处理}

从水库上游到下游, 依据水库结构及吞吐流特征, 纵向可分为河流区 (上游) - 过渡区 (中游) - 湖泊区 (下游) 等不同梯级区域, 在不同区域再根据水库功能将采样站位具体化. 南湾水库划分为 4 个分区, 每个分 区设 1 2 个采样站位,共计 9 个采样站位（图 1). 其中站位 9 位于河流区,站位 3.7 位于河湖过渡区,站位 $1 、 2$ 位于湖泊区,站位 4、5、6、8 位于库湾区. 自 2015 年 11 月- 2016 年 9 月按季节进行采样: 冬季 ( 2015 年 11 月)、春季( 2016 年 3 月)、夏季 ( 2016 年 7 月)、秋季 ( 2016 年 9 月).

汤浦水库划分为 4 个分区, 每个分区设 1 2 个采样站位, 共计 6 个采样站位 (图 1). 其中站位 $1 、 2$ 位于 河流区,站位 $3 、 4$ 位于河湖过渡区,站位 6 位于湖泊区,站位 5 位于库湾区. 自 2010 年 7 月至 2011 年 11 月 分 5 个时段进行样品采集,分别为 2010 年 7 月、 10 月, 2011 年 4 月、 5 月和 7 月.
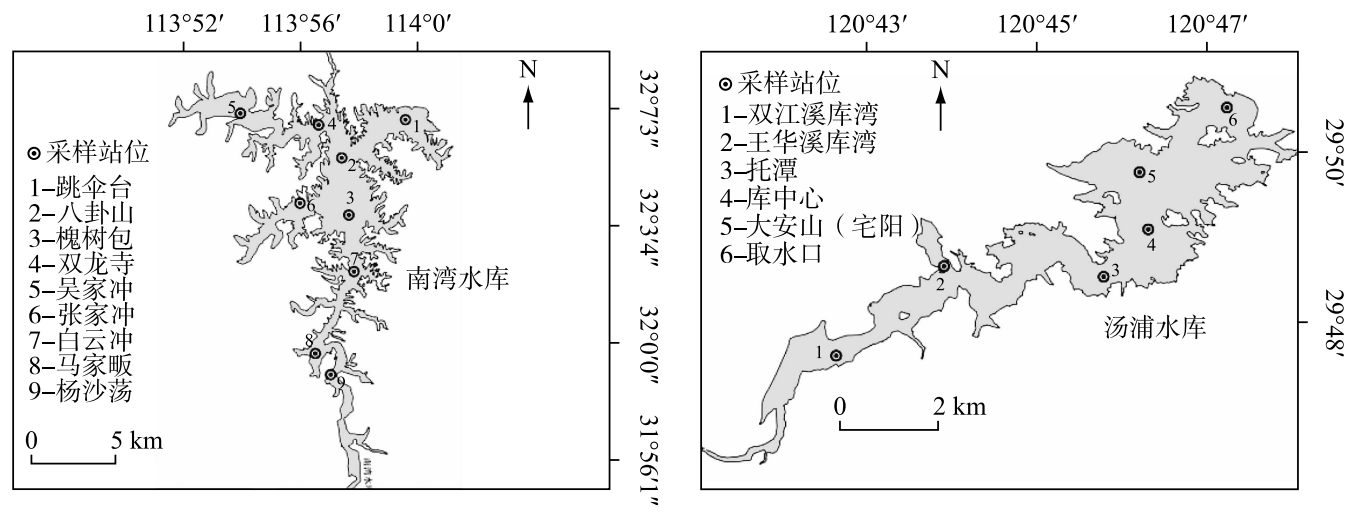

图 1 南湾水库和汤浦水库采样站位示意

Fig.1 Distribution of sampling sites in Nanwan Reservoir and Tangpu Reservoir

采用改良彼得逊采泥器 $\left(1 / 16 \mathrm{~m}^{2}\right)$ 进行底栖动物样品采集, 每个站位采集 $2 \sim 4$ 个重复样合并成一个大 样. 采集的泥样经 60 目 $(250 \mu \mathrm{m})$ 篮绢布用篎选干净后, 将样品放人封口袋中带回室内进行分拣, 然后置人 $100 \mathrm{~mL}$ 的塑料标本瓶中, 用 $10 \%$ 的福尔马林液进行固定保存. 浮游植物、原生动物和轮虫定量样品采用 $5 \mathrm{~L}$ 有机玻璃采水器采集表层、中层和下层的水样等体积均匀混合后, 取 $2 \mathrm{~L}$ 水样按 $1.5 \%$ 加人鲁哥试剂现场固 定, 送人实验室静置沉淀浓缩至 $30 \mathrm{~mL}$ 后镜检备用. 浮游甲壳动物定量样品采用 25 号浮游生物网过滤取自 表层、中层和下层的 $20 \mathrm{~L}$ 混合水获取定量标本. 采集生物样品的同时同步采集水样,带回实验室测定水体总 氮 $(\mathrm{TN})$ 、总磷 $(\mathrm{TP})$ 、高锰酸盐指数 $\left(\mathrm{COD}_{\mathrm{Mn}}\right)$ 和叶绿素 $a(\mathrm{Chl} . a)$ 浓度. 各指标的测定方法按照参照《水和废 水监测分析方法》进行 ${ }^{[27]}$. 野外采用 YSI Plus 多功能水质分析仪同步测定 $\mathrm{pH}$ 、溶解氧浓度, 采用塞氏盘测定 水体透明度.

\section{3 样品鉴定}

底栖动物标本送人实验室采用 Olympus CX41 显微镜和 Leica EZ4D 解剖镜进行鉴定. 鉴定时, 水生昆虫 除摇蚊类鉴定到属外鉴定到科, 塞毛类和软体动物鉴定到属或种, 其他类群鉴定到门或纲 ${ }^{[28-29]}$. 底栖动物标 本鉴定后进行计数称重, 按采样面积分别折算成密度 (ind. $/ \mathrm{m}^{2}$ ) 和生物量 (湿重 $\mathrm{g} / \mathrm{m}^{2}$ ). 浮游生物标本采用 Olympus CX41 显微镜进行镜检. 浮游植物计数前充分摇匀样品, 取 $0.1 \mathrm{~mL}$ 样品于 $0.1 \mathrm{~mL}$ 计数框内进行视野 
法计数, 原生动物和轮虫计数合用浮游植物样品, 取 $1 \mathrm{~mL}$ 定量样品显微镜下计数, 重复取样 3 次取均值. 浮 游甲壳动物标本在 Leica EZ4D 解剖镜下全部计数. 浮游植物的鉴定主要参照《中国淡水藻类——系统、分类 及生态 ${ }^{[30]}$, 原生动物和轮虫的鉴定主要参照《淡水浮游生物研究方法》和《微型生物监测新技术》 ${ }^{[31-32]}$. 浮 游甲壳动物的鉴定主要参照《中国动物志一一节肢动物门·甲壳纲·淡水枝角类》和《中国动物志——节肢动 物门·甲壳纲・淡水桡足类 $\rangle^{[33-34]}$. 浮游生物鉴定到种属水平, 并计算各个类群的密度 (浮游植物 $\mathrm{cell} / \mathrm{s} / \mathrm{L}$, 浮游 动物 ind. $/ \mathrm{L}$ ).

\section{4 数据分析}

底栖动物优势种根据每个种的优势度 $(Y)$ 来确定: $Y=f_{i}\left(n_{i} / N\right)$, 式中, $n_{i}$ 为第 $i$ 种的个体数, $N$ 为所有 种类总个体数, $f_{i}$ 为第 $i$ 种的出现频率. $Y$ 值大于 0.02 的种类为优势种 ${ }^{[35]}$. 采用群落状态指数 IICS (integral index of communities state) 分别评估两座水库的底栖动物群落状态. 该指数采用四个指标来对水库中底栖动 物群落结构的整体状态进行评估, 分别为底栖动物的密度 $R_{N}\left(\right.$ ind. $\left./ \mathrm{m}^{2}\right)$ 、生物量 $R_{B}\left(\mathrm{~g} / \mathrm{m}^{2}\right)$ 、单站物种数 $R_{S}$ 和 Shannon-Wiener 指数 $R_{H}$. 该指数基于秩排序计算综合得分, IICS $=\left(\sum_{1}^{k} P_{i} \cdot R_{i}\right) / \sum_{1}^{k} P_{i}$, 式中, $R_{i}$ 为第 $i$ 指 标的秩得分 (秩 1 对应单个指标的最大值), $P_{i}$ 为第 $i$ 指标的权重. 本文中 $I I C S=\left(R_{N}+2 R_{B}+R_{S}+R_{H}\right) / 5$. 底 栖动物的现存量和多样性越高, 表明底栖动物群落状态越好, IICS 分值越低, 反之, IICS 分值越高 ${ }^{[36]}$. 采用 偏最小二乘法 (partial least-square method,PLS) 构建模型来判断各浮游生物类群密度对 IICS 分值的影响程 度, 变量权重因子大于 0.20 表明其对 IICS 分值有重要影响, 是很好的预测变量 ${ }^{[37]}$. 采用 Spearman 秩相关和 回归图探讨浮游生物各类群 (浮游植物、原生动物、轮虫和浮游甲壳动物) 密度与 IICS 的关系. 计算各个水 库水体总氮和总磷浓度比, 简称氮磷比 ( N/P), 从而判断水库是氮抑制性水库还是磷抑制性水库 ${ }^{[38]}$. MannWhitney 检验等常规统计分析和 PLS 模型的构建采用 SPSS V20.0 进行.

\section{2 结果与分析}

\section{1 水体营养状态比较分析}

调查期间, 南湾水库浮游植物总平均密度为 $8.80 \times 10^{6} \mathrm{cells} / \mathrm{L}$, 其中 2015 年 11 月平均密度为 $1.24 \times 10^{7}$ cells $/ \mathrm{L}, 2016$ 年 3 月为 $2.50 \times 10^{6}$ cells $/ \mathrm{L}, 7$ 月为 $7.37 \times 10^{6}$ cells $/ \mathrm{L}, 9$ 月为 $1.30 \times 10^{7}$ cells $/ \mathrm{L}($ 图 $2 \mathrm{~A})$. 汤浦水库浮 游植物总平均密度达 $7.07 \times 10^{6} \mathrm{cells} / \mathrm{L}$, 其中 2010 年 7 月为 $2.67 \times 10^{6} \mathrm{cells} / \mathrm{L}, 10$ 月为 $6.25 \times 10^{6} \mathrm{cells} / \mathrm{L}, 2011$ 年 4 月平均密度为 $2.09 \times 10^{7} \mathrm{cells} / \mathrm{L}, 5$ 月为 $3.92 \times 10^{6} \mathrm{cells} / \mathrm{L}, 7$ 月为 $1.65 \times 10^{6} \mathrm{cells} / \mathrm{L}($ 图 $2 \mathrm{~B})$. 根据藻类密度 来看, 两座水库浮游植物总平均密度均超过 $10^{6} \mathrm{cell} / \mathrm{s} / \mathrm{L}$, 具备藻类水华发生的条件 (见全国重点湖库藻类试 点监测技术规程), 其中南湾水库秋冬季 (2015 年 11 月和 2016 年 9 月) 和汤浦水库春季 (2011 年 4 月) 浮游 植物平均密度超过 $10^{7} \mathrm{cells} / \mathrm{L}$. 就浮游植物门类组成来看, 南湾水库蓝藻门占据绝对优势地位, 为蓝藻占优 势的水库, 而汤浦水库硅藻门占据优势地位, 为硅藻占优势的水库 (图 3).

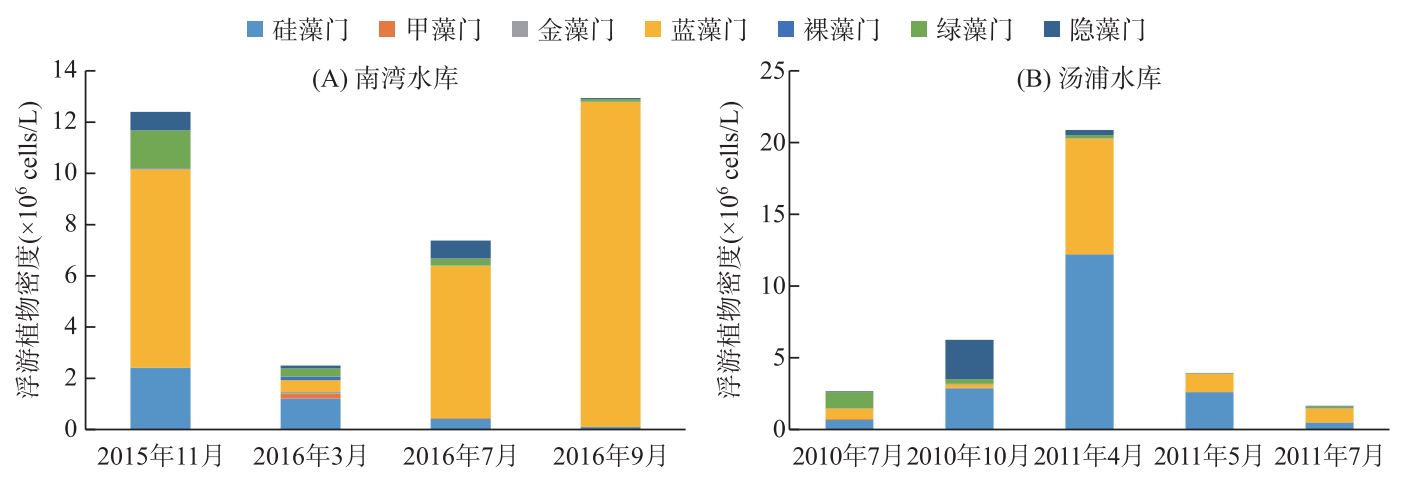

图 2 两座水库浮游植物不同采样时段密度组成

Fig.2 The density composition of phytoplankton groups in two reservoirs at different sampling periods 
表 1 调查期间两座水库的水质理化特性

Tab.1 The physicochemical characteristics of waterbody from two reservoirs during investigation periods

\begin{tabular}{ccc}
\hline 参数 & 南湾水库 & 汤浦水库 \\
\hline $\mathrm{Chl} . a /(\mu \mathrm{g} / \mathrm{L})$ & $14.21 \pm 9.15$ & $6.60 \pm 7.58$ \\
$\mathrm{COD}_{\mathrm{Mn}} /(\mathrm{mg} / \mathrm{L})$ & $6.89 \pm 5.18$ & $2.07 \pm 1.45$ \\
$\mathrm{DO} /(\mathrm{mg} / \mathrm{L})$ & $8.71 \pm 2.21$ & $9.10 \pm 2.49$ \\
$\mathrm{pH}$ & $8.38 \pm 0.35$ & $7.29 \pm 0.91$ \\
$\mathrm{SD} / \mathrm{m}$ & $1.79 \pm 1.24$ & $2.06 \pm 0.95$ \\
$\mathrm{TN} /(\mathrm{mg} / \mathrm{L})$ & $1.03 \pm 0.44$ & $2.11 \pm 0.68$ \\
$\mathrm{TP} /(\mathrm{mg} / \mathrm{L})$ & $0.029 \pm 0.009$ & $0.027 \pm 0.067$ \\
$\mathrm{~N} / \mathrm{P}$ & $38.13 \pm 15.51$ & $123.37 \pm 64.93$ \\
\hline
\end{tabular}

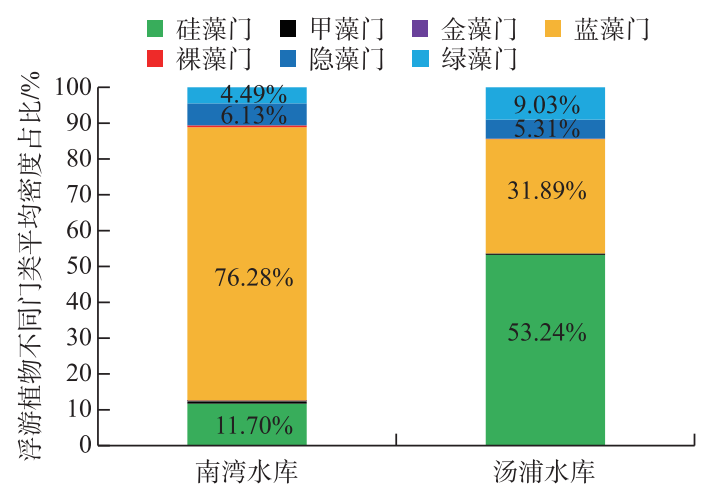

图 3 调查期间两座水库浮游植物各门类组成比例

Fig. 3 The proportions of different phyla of phytoplankton in the two reservoirs during investigation periods
就水体理化性质而言,南湾水库的 Chl. $a$ 浓度远 高于汤浦水库, 高锰酸盐指数是汤浦水库的 3.33 倍, 水体由于藻类丰度较高处于弱碱性, 而汤浦水库由 于藻类丰度相对较低水体基本处于中性状态. 两座 水库的总磷水平较为接近, 但南湾水库的水体透明 度和总氮水平要低于汤浦水库. 南湾水库的氮磷比 为 38.13 , 汤浦水库的氮磷比为 123.37 (表 1 ).

就不同时段而言,南湾水库水温较高的 7 月和 9 月,Chl. $a$ 浓度和 $\mathrm{pH}$ 要明显高于水温较低的 3 月,而 透明度则正好相反; 汤浦水库一年的时段中, 自 4 月 后, 透明度急剧下降, $5-8$ 月处于藻类急剧增长阶段, Chl. $a$ 浓度和 $\mathrm{pH}$ 明显高于其他时段. 从两座水库不同 时段的理化性质结果来看,热分层期间藻类基本处于 急剧增殖阶段, 透明度要明显低于其他时段, $\mathrm{pH}$ 和 Chl. $a$ 浓度则明显高于其他时段, 这表明两座水库的 富营养化与热分层基本处于同步耦合状态 (表 2).

\section{2 底栖动物群落结构比较}

南湾水库 4 次调查共检出底栖动物 20 种, 隶属 6 科 16 属, 其中水生昆虫 12 种, 寡毛类 7 种, 线虫 1 种, $\mathrm{r}$-对策者类型有 20 种, $\mathrm{K}$-对策者 0 种. 全年来看, 优势种为霍甫水丝蚓 Limnodrilus hoffmeisteri、裸须摇 蚊 Propsilocerus sp. 和前突摇蚊 Procladius sp.; 汤浦水 库 5 次调查共采集到底栖动物 27 种, 其中水生昆虫 摇蚊类 17 种, 软体动物 2 种, 寡毛类 7 种, 线虫 1 种, $\mathrm{r}$-对策者类型有 25 种, $\mathrm{K}$-对策者 2 种. 优势种为霍甫 水丝蚓和前突摇蚊 (表 3 ). 就不同类群而言, 南湾水 库以寡毛类为主, 而汤浦水库则以水生昆虫为主 (图 $4 \mathrm{~A})$. 就摄食功能类群而言, 南湾水库收集者占据绝 对主导优势地位, 相比较而言, 汤浦水库收集者数量

百分比远低于南湾水库 (图 4B). 就不同时期而言, 南湾水库热分层期间 (2016 年 7 月和 9 月) 检出的物种数 分别为 8 和 6 种,远少于春季的 16 种和冬季的 14 种,汤浦水库在热分层期间 (2010 年 7 月、2011 年 4 月、 5 月、7 月) 检出的物种数分别为 $8 、 8 、 9$ 和 6 种, 远少于 2010 年 10 月的 13 种.

\section{3 底栖动物现存量和多样性比较分析}

经 Mann-Whitney 检验, 就底栖动物现存量而言, 南湾水库密度显著高于汤浦水库, 而生物量却显著低于 汤浦水库; 就 Shannon-Wiener 指数和单站出现的物种数而言, 两座水库差异不显著, 但 Shannon-Wiener 指数 均值南湾水库稍低于汤浦水库,而单站物种数均值南湾水库略高于汤浦水库 (表 4).

就具体采样时段来看, 南湾水库热分层期间 (2016 年 7 月和 9 月) 的底栖动物密度、单站物种数和 Shannon-Wiener 指数的均值明显低于水温较低的 2015 年 11 月和 2016 年 3 月; 汤浦水库热分层期间 (2010 年 7 月、 2011 年 4 月、 5 月和 7 月) 的底栖动物单站物种数和 Shannon-Wiener 指数的均值均低于 2010 年 10 月 (表 5).

\section{4 底栖动物群落结构状态与浮游生物关系}

以 IICS 为因变量 (图 $5 \mathrm{~A}$ 和图 5B), 以浮游生物各类群密度为自变量, 分别针对南湾水库和汤浦水库构 建 PLS 模型. 由于潜在因子 1 解释的方差最大, 是很好的预测因子, 因此我们考察各变量在潜在因子 1 中的 权重 (表 6). 由表 6 可以看出: 在南湾水库中, 原生动物密度、轮虫密度、浮游甲壳动物密度和浮游植物密度 
均对 IICS 分值有重要影响, 是很好的预测变量; 在汤浦水库中, 原生动物密度、轮虫密度和浮游植物密度也 对 IICS 分值有重要影响, 可以很好地预测 IICS.

表 2 两座水库不同调查时段的水质理化特性

Tab.2 The physicochemical characteristics of waterbody from two reservoirs at different investigation periods

\begin{tabular}{|c|c|c|c|c|c|c|c|c|}
\hline 水库 & 时段 & $\begin{array}{c}\mathrm{TN} / \\
(\mathrm{mg} / \mathrm{L})\end{array}$ & $\begin{array}{c}\mathrm{TP} / \\
(\mathrm{mg} / \mathrm{L})\end{array}$ & $\mathrm{N} / \mathrm{P}$ & $\begin{array}{l}\text { Chl.a/ } \\
(\mu \mathrm{g} / \mathrm{L})\end{array}$ & $\begin{array}{c}\mathrm{SD} / \\
\mathrm{m}\end{array}$ & $\begin{array}{c}\mathrm{DO} / \\
(\mathrm{mg} / \mathrm{L})\end{array}$ & $\mathrm{pH}$ \\
\hline \multirow[t]{4}{*}{ 南湾水库 } & 2015 年 11 月 & 0.99 & 0.026 & 40.78 & 11.92 & 1.11 & 6.61 & 8.05 \\
\hline & 2016 年 3 月 & 1.10 & 0.038 & 29.64 & 4.72 & 3.50 & 10.41 & 8.22 \\
\hline & 2016 年 7 月 & 1.11 & 0.021 & 50.94 & 13.11 & 1.60 & 7.02 & 8.59 \\
\hline & 2016 年 9 月 & 0.90 & 0.030 & 32.00 & 26.32 & 0.96 & 10.36 & 8.64 \\
\hline \multirow[t]{12}{*}{ 汤浦水库 } & 2011 年 1 月 & 2.34 & 0.016 & 193.37 & 1.39 & 3.5 & 8.90 & 6.75 \\
\hline & 2011 年 2 月 & 2.27 & 0.012 & 198.87 & 3.26 & 2.23 & 11.27 & 6.91 \\
\hline & 2011 年 3 月 & 2.41 & 0.016 & 197.17 & 2.55 & 2.41 & 11.47 & 6.92 \\
\hline & 2011 年 4 月 & 2.21 & 0.021 & 121.55 & 4.07 & 2.39 & 10.38 & 7.07 \\
\hline & 2011 年 5 月 & 1.83 & 0.029 & 94.42 & 14.23 & 1.33 & 11.37 & 8.38 \\
\hline & 2011 年 6 月 & 2.81 & 0.092 & 117.83 & 4.18 & 1.33 & 8.06 & 7.15 \\
\hline & 2011 年 7 月 & 2.17 & 0.027 & 87.77 & 15.49 & 1.33 & 8.35 & 8.05 \\
\hline & 2011 年 8 月 & 2.07 & 0.022 & 114.00 & 11.29 & 1.36 & 8.29 & 8.19 \\
\hline & 2011 年 9 月 & 1.67 & 0.014 & 147.36 & 3.12 & 2.53 & 7.18 & 6.99 \\
\hline & 2011 年 10 月 & 1.82 & 0.025 & 81.85 & 6.08 & 2.79 & 7.75 & 6.95 \\
\hline & 2011 年 11 月 & 1.95 & 0.026 & 86.81 & 4.75 & 2.70 & 7.25 & 6.83 \\
\hline & 2011 年 12 月 & 1.93 & 0.022 & 94.48 & 3.92 & 2.06 & 8.74 & 6.80 \\
\hline
\end{tabular}

Spearman 秩相关分析结果表明: 在南湾水库中, IICS 分值与原生动物密度 $(\rho=0.504)$ 和浮游植物密度 $(\rho=0.506)$ 呈显著正相关关系 $(P<0.01)$, 而在汤浦水库中则与原生动物密度呈显著负相关关系 $(\rho=-0.597$, $P<0.01)$. 回归图分析表明南湾水库中原生动物、浮游甲壳动物和浮游植物的密度与 IICS 分值具有较好的 线性关系,而在汤浦水库中, 原生动物和轮虫的密度也与 IICS 分值具有较好的线性关系( 图 6 和图 7).

\section{3 讨论}

\section{1 两座水库的营养状态和底栖动物群落结构}

南湾水库水质在 1998 年以前较为良好,随后动荡变化不定, 2007 年 8-9 月间的藻类水华的出现标志 该水库局部水体接近或已经进人富营养状态 ${ }^{[22]}$. 该水库日益突出的富营养化现象与库区旅游业以及库周 沿岸茶叶与板栗种植业的高速发展导致大量有机物质和营养盐类进人水体, 进而导致水体中总氮和总磷浓 度超标频率较高有关 ${ }^{[20,39]}$. 本次调查发现, 南湾水库总氮、总磷浓度较高, 其中总氮水平介于地表水 III IV 类之间, 总磷水平超过地表水 II 类限值. 较高的总氮、总磷浓度会引起库区水体富营养化和藻类过度繁殖, 甚至发生蓝藻水华, 进而产生微囊藻毒素威胁水库水质 ${ }^{[23,40-41]}$. 总氮均值 $1.03 \mathrm{mg} / \mathrm{L}$, 接近 2007 年的 1.05 $\mathrm{mg} / \mathrm{L}$; 总磷均值 $0.029 \mathrm{mg} / \mathrm{L}$, 接近 2008 年的 $0.021 \mathrm{mg} / \mathrm{L}^{[20]}$. 历史资料显示, 南湾水库 Chl. $a$ 浓度 1997 年为 $1.11 \mu \mathrm{g} / \mathrm{L}, 2005$ 年为 $26 \mu \mathrm{g} / \mathrm{L}^{[22]}$, 本次调查为 $14.21 \mu \mathrm{g} / \mathrm{L}$, 虽然较 2005 年有所下降, 但仍远高于 1997 年的 水平. 汤浦水库上游溪流较重的农业面源污染将大量的营养物质带人库区, 造成水体氮、磷浓度过高, 为库 区藻类的过量繁殖提供了物质基础. 资料显示, 在 2002-2005 年库区上游暴发过 3 次藻类水华, 其中 2003 年 5 月的藻类水华最为严重, 持续时间长达 40 天, 全库水面被褐色水华覆盖, 溶解氧小于 $2.0 \mathrm{mg} / \mathrm{L}^{[21]} ; 2011$ 年 4 月监测到库区暴发硅藻水华 ${ }^{[42-44]}$. 本次调查显示, 汤浦水库总氮浓度均值 $2.11 \mathrm{mg} / \mathrm{L}$, 超地表水 $\mathrm{V}$ 类限 值; 总磷浓度均值 $0.027 \mathrm{mg} / \mathrm{L}$, 超地表水 II 类限值, 处于中度富营养化水平 ${ }^{[21]}$. 相比较而言, 汤浦水库总氮 含量要远高于南湾水库, 总磷水平两座水库较为接近, 氮磷比两座水库均远高于 7.2 , 为磷抑制性水库 ${ }^{[38]}$, 但 汤浦水库要远高于南湾水库, 表明汤浦水库受磷限制更为严重 ${ }^{[26]}$. 就底栖动物而言, 这两座水库出现的种类 
表 3 研究区域底栖动物名录

Tab.3 List of macroinvertebrates in the study areas

\begin{tabular}{|c|c|c|c|c|c|}
\hline \multirow{2}{*}{$\begin{array}{l}\text { 物种 } \\
\text { 水生昆虫 Aquatic insects }\end{array}$} & & \multicolumn{4}{|c|}{ 对策类型 功能摄食类群 南湾水库 汤浦水库 } \\
\hline & & & & & \\
\hline \multirow[t]{19}{*}{ 摇蚊科 Chironomidae } & 矮突摇蚊 Nanocladius sp. & r-对策者 & 收集者 & + & \\
\hline & 齿斑摇蚊 Stictochironomus sp. & r-对策者 & 收集者 & + & + \\
\hline & 裸须摇蚊 Propsilocerus sp. & r-对策者 & 收集者 & + & + \\
\hline & 异腹摇蚊 Einfeldia sp. & r-对策者 & 收集者 & + & \\
\hline & 长足摇蚊 Tanypus sp. & $\mathrm{r}$-对策者 & 捕食者 & + & + \\
\hline & 直突摇蚊 Orthocladius sp. & r-对策者 & 收集者 & + & \\
\hline & 前突摇蚊 Procladius sp. & $\mathrm{r}$-对策者 & 捕食者 & + & + \\
\hline & 隐摇蚊 Cryptochironomus sp. & $\mathrm{r}$-对策者 & 捕食者 & & + \\
\hline & 枝角摇蚊 Cladopelma sp. & r-对策者 & 收集者 & & + \\
\hline & 雕翅摇蚊 Glyptotendipes sp. & r-对策者 & 撕食者 & & + \\
\hline & 多足摇蚊 Polypedilum sp. & r-对策者 & 撕食者 & & + \\
\hline & 长跗摇蚊 Tanytarsus sp. & r-对策者 & 滤食者 & & + \\
\hline & 流水长跗摇蚊 Rheotanytarsus sp. & r-对策者 & 滤食者 & & + \\
\hline & 林摇蚊 Lipiniella sp. & r-对策者 & 收集者 & & + \\
\hline & 小摇蚊 Microchironomus sp. & r-对策者 & 收集者 & & + \\
\hline & 哈尼摇蚊 Harnischia sp. & r-对策者 & 收集者 & & + \\
\hline & 摇蚊 Chironomus sp.1 & r-对策者 & 收集者 & + & \\
\hline & 摇蚊 Chironomus sp.2 & r-对策者 & 收集者 & & + \\
\hline & 摇蚊蛹 Chironomidae pupae & & & + & + \\
\hline 大蜻科 Macromiidae & 大蜻 Macromiidae sp. & $\mathrm{r}$-对策者 & 捕食者 & + & \\
\hline 幽蚊科 Chaoboridae & 幽蚊 Chaoboridae sp. & r-对策者 & 捕食者 & + & \\
\hline 蠓科 Ceratopogonidae & 蠓 Ceratopogonidae sp. & r-对策者 & 捕食者 & + & \\
\hline \multicolumn{6}{|l|}{ 软体动物 Mollusc } \\
\hline 贻贝科 Mytidea & 淡水壳菜 Limnoperna fortunei & K-对策者 & 滤食者 & & + \\
\hline 田螺科 Vivipariidae & 梨形环棱螺 Bellamya purificata & K-对策者 & 刮食者 & & + \\
\hline \multicolumn{6}{|c|}{ 水栖寡毛类 Aquatic oligochaetes } \\
\hline \multirow[t]{9}{*}{ 颤蚓科 Tubificidae } & 多毛管水蚓 Aulodrilus pluriseta & r-对策者 & 收集者 & + & \\
\hline & 日本管水蚓 Aulodrilus japonicus & r-对策者 & 收集者 & & + \\
\hline & 管水蚓属 Aulodrilus sp. & r-对策者 & 收集者 & + & + \\
\hline & 厚唇嫩丝蚓 Teneridrilus mastix & r-对策者 & 收集者 & + & \\
\hline & 霍甫水丝蚓 Limnodrilus hoffmeisteri & r-对策者 & 收集者 & + & + \\
\hline & 钝毛水丝蚓 Limnodrilus amblysetus & r-对策者 & 收集者 & & + \\
\hline & 巨毛水丝蚓 Limnodrilus grandisetosus & r-对策者 & 收集者 & + & + \\
\hline & 克拉泊水丝蚓 Limnodrilus claparedeianus & r-对策者 & 收集者 & + & \\
\hline & 苏氏尾鳃蚓 Branchiura sowerbyi & r-对策者 & 收集者 & + & + \\
\hline 其他类群 Others & 线虫 Nematoda & r-对策者 & 捕食者 & + & + \\
\hline
\end{tabular}

数均不超过 30 种, 较为典型的富营养化指示种如霍甫水丝蚓和前突摇蚊在这两座水库中均为优势种. 研究 表明, 裸须摇蚊 (德永摇蚊) 也是典型的富营养化水体的指示生物 ${ }^{[45]}$, 该物种广泛分布于我国南北方的湖泊 和水库水体中并成为优势种 ${ }^{[46-49]}$. 裸须摇蚊在南湾水库为优势种, 更进一步证实该水库已经富营养化. 就藻 类组成来看, 南湾水库蓝藻占据绝对优势地位, 更易暴发蓝藻水华, 而汤浦水库硅藻占据优势, 更易暴发硅 藻水华. 就叶绿素 $a$ 水平而言, 南湾水库远高于汤浦水库, 表明其富营养程度要高于汤浦水库. 就底栖动物 类群而言, 南湾水库寡毛类在数量上占据优势地位, 而汤浦水库则以水生昆虫中的摇蚊类在数量上占优; 就 摄食功能群而言, 南湾水库以收集者为主, 其数量占比要远高于汤浦水库, 这似乎表明, 寡毛类和收集者更 
(A) 底栖动物类群

寡毛类 $\square$ 其他类群 $\square$ 软体动物 $\because$ 水生昆虫

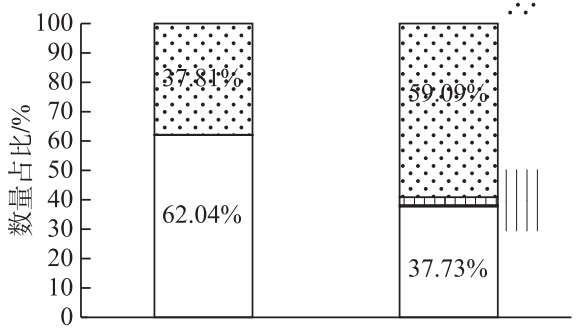

南湾水库

汤浦水库
(B) 摄食功能类群
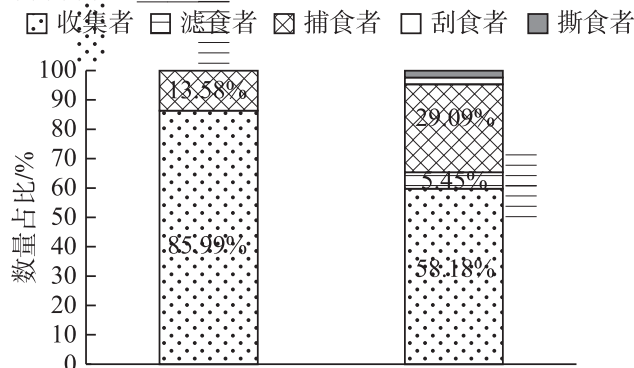

南湾水库

汤浦水库

图 4 两座水库的底栖动物类群和摄食功能类群组成比例

Fig.4 The abundance percentages of different groups and functional feeding groups of macroinvertebrates in the two reservoirs

表 4 两座水库底栖动物现存量、单站物种数和多样性指数比较

Tab.4 Comparison of standing crops, taxa per site and Shannon-Wiener index of macroinvertebrates in two reservoirs

\begin{tabular}{ccccc}
\hline 水库 & 密度 $/\left(\right.$ ind. $\left./ \mathrm{m}^{2}\right)$ & 生物量 $/\left(\mathrm{g} / \mathrm{m}^{2}\right)$ & 单站物种数 & Shannon-Wiener 指数 \\
\hline 南湾水库 & $171.43 \pm 261.81$ & $0.50 \pm 0.91$ & $2.9 \pm 1.7$ & $0.66 \pm 0.47$ \\
& $(0 \sim 1376)$ & $(0 \sim 5.33)$ & $(0 \sim 7)$ & $(0 \sim 1.40)$ \\
汤浦水库 & $83.88 \pm 127.82$ & $1.18 \pm 5.30$ & $2.2 \pm 2.2$ & $0.88 \pm 0.53$ \\
& $(0 \sim 600)$ & $(0 \sim 29.48)$ & $(0 \sim 7)$ & $(0 \sim 1.89)$ \\
Mann-Whitney U & 361.5 & 195.0 & 421.0 & 282.0 \\
$Z$ & -2.305 & -4.516 & -1.555 & -1.195 \\
$P$ & 0.021 & $<0.001$ & 0.232 & 0.120 \\
\hline
\end{tabular}

适应在富营养程度较高的水库中生存.

\section{2 水温分层及富营养化对底栖动物的影响效应}

大多数温带及亚热带的深水湖泊及水库都会在气温较高的季节出现水温分层现象,同为丘陵型水库的 南湾水库和汤浦水库也不例外 ${ }^{[26,50]}$. 水库在水温分层节律、溶解氧动态变化过程以及水力停留时间等方面 均不同于天然湖泊和河流 ${ }^{[51]}$, 其热分层和富营养化对溶解氧浓度的垂向分布有很大影响 ${ }^{[4]}$. 有研究表明, 汤浦水库水体表温层溶解氧基本处于饱和状态, 最高可达 $14.8 \mathrm{mg} / \mathrm{L}$, 在不存在水温分层的情况下, 溶解氧 分布均匀, 几乎不受水深影响, 但在水体出现热分层现象时, 生物呼吸、藻类尸体分解及还原性物质的氧化 等活动持续消耗水中溶解氧, 导致溶解氧呈现类似温度的梯度分布, 库底最低时几乎为零 ${ }^{[26]}$. 南湾水库也 存在类似情况, 由于夏季藻类过度生长, 死亡的藻类残骸沉人水体下层并发生腐烂、分解等耗氧作用, 水温 分层现象阻碍了上下水层的溶解氧交换, 进而造成水体在夏季的底部缺氧状态 ${ }^{[20]}$. 研究表明, 由于耐受能 力差, 对氧敏感的底栖动物种类会因低氧而减少或消失, 而持续厌氧不仅会降低个体种类的丰度及季节与 年度生长率, 而且会极大地降低种类丰富度与群落生产力 ${ }^{[52-56]}$, 与此同时, 由于溶解氧限制, 浮游生物会存 在明显的垂向迁移行为. 南湾水库的相关调查资料表明, 水温较高的夏季, 浮游生物下层水体的生物量要低 于中上层水体 ${ }^{[57]}$. 汤浦水库的调查资料也发现浮游植物数量在进人变温层后急剧下降, 至底温层后才平稳 维持在一定的数量 ${ }^{[26]}$. 国外的一些研究案例也表明浮游动物的垂向迁徙与溶解氧垂向分布有较大关系. 如 在墨西哥北部湾, 当水体底部溶解氧水平不足 $2 \mathrm{mg} / \mathrm{L}$ 时, 浮游动物会由浑浊的深水层向表层垂直迁徙 ${ }^{[58]}$; 在浅水湖沼系统中, 当水体底部溶解氧水平趋近于零时, 浮游动物由于溶解氧的限制向上层迁徙, 其丰度水 平远高于中下层 ${ }^{[59]}$. 浮游生物的垂向迁移行为会导致水体底部食物来源的匮乏 ${ }^{[60-61]}$, 这些均是底栖动物的 分布和生长繁殖的限制因素 ${ }^{[52-53]}$. 相比较而言, 浅水湖泊的富营养化会促进底栖动物密度的持续增长 ${ }^{[62-64]}$, 
表 5 两座水库在不同时段的底栖动物现存量、单站物种数和多样性指数

Tab.5 The standing crops, taxa per site and Shannon-Wiener index of two reservoirs in different periods

\begin{tabular}{|c|c|c|c|c|c|}
\hline 水库 & 时间 & 密度/(ind. $\left./ \mathrm{m}^{2}\right)$ & 生物量 $/\left(\mathrm{g} / \mathrm{m}^{2}\right)$ & 单站物种数 & Shannon-Wiener 指数 \\
\hline \multirow[t]{4}{*}{ 南湾水库 } & 2016 年 3 月 & $\begin{array}{c}400.89 \pm 434.48 \\
\quad(72 \sim 1376)\end{array}$ & $\begin{array}{c}1.49 \pm 1.46 \\
(0.52 \sim 5.33)\end{array}$ & $\begin{array}{c}4.8 \pm 1.7 \\
(2 \sim 7)\end{array}$ & $\begin{array}{c}0.89 \pm 0.30 \\
(0.43 \sim 1.33)\end{array}$ \\
\hline & 2016 年 7 月 & $\begin{array}{c}74.67 \pm 71.44 \\
\quad(8 \sim 232)\end{array}$ & $\begin{array}{c}0.22 \pm 0.09 \\
(0.02 \sim 0.32)\end{array}$ & $\begin{array}{c}2.3 \pm 1.2 \\
(1 \sim 4)\end{array}$ & $\begin{array}{l}0.62 \pm 0.54 \\
(0 \sim 1.27)\end{array}$ \\
\hline & 2016 年 9 月 & $\begin{array}{c}83.33 \pm 106.32 \\
(8 \sim 330.67)\end{array}$ & $\begin{array}{l}0.09 \pm 0.09 \\
(0 \sim 0.26)\end{array}$ & $\begin{array}{l}1.7 \pm 0.9 \\
(1 \sim 3)\end{array}$ & $\begin{array}{l}0.33 \pm 0.45 \\
(0 \sim 1.06)\end{array}$ \\
\hline & 2015 年 11 月 & $\begin{array}{l}112.80 \pm 119.58 \\
\quad(8 \sim 312)\end{array}$ & $\begin{array}{c}0.17 \pm 0.14 \\
(0.01 \sim 0.42)\end{array}$ & $\begin{array}{l}3.0 \pm 1.1 \\
(2 \sim 5)\end{array}$ & $\begin{array}{c}0.79 \pm 0.43 \\
(0.12 \sim 1.40)\end{array}$ \\
\hline \multirow[t]{5}{*}{ 汤浦水库 } & 2010 年 7 月 & $\begin{array}{l}79.33 \pm 120.17 \\
\quad(0 \sim 312)\end{array}$ & $\begin{array}{l}0.10 \pm 0.17 \\
(0 \sim 0.42)\end{array}$ & $\begin{array}{l}1.8 \pm 1.7 \\
(0 \sim 4)\end{array}$ & $\begin{array}{l}0.50 \pm 0.48 \\
(0 \sim 0.74)\end{array}$ \\
\hline & 2010 年 10 月 & $\begin{array}{c}109.33 \pm 120.76 \\
\quad(0 \sim 304)\end{array}$ & $\begin{array}{l}0.07 \pm 0.08 \\
(0 \sim 0.18)\end{array}$ & $\begin{array}{c}3.5 \pm 3.0 \\
(0 \sim 7)\end{array}$ & $\begin{array}{l}1.14 \pm 0.96 \\
(0 \sim 1.89)\end{array}$ \\
\hline & 2011 年 4 月 & $\begin{array}{c}64 \pm 66.36 \\
(0 \sim 160)\end{array}$ & $\begin{array}{l}5.01 \pm 11.99 \\
(0 \sim 29.48)\end{array}$ & $\begin{array}{c}2.2 \pm 1.5 \\
(0 \sim 4)\end{array}$ & $\begin{array}{l}0.71 \pm 0.55 \\
(0 \sim 1.17)\end{array}$ \\
\hline & 2011 年 5 月 & $\begin{array}{c}128 \pm 235.97 \\
(0 \sim 600)\end{array}$ & $\begin{array}{l}0.06 \pm 0.12 \\
(0 \sim 0.29)\end{array}$ & $\begin{array}{c}2.2 \pm 2.8 \\
(0 \sim 7)\end{array}$ & $\begin{array}{l}1.12 \pm 1.08 \\
(0 \sim 1.65)\end{array}$ \\
\hline & 2011 年 7 月 & $\begin{array}{c}36 \pm 50.53 \\
(0 \sim 112)\end{array}$ & $\begin{array}{l}0.69 \pm 1.65 \\
(0 \sim 4.06)\end{array}$ & $\begin{array}{l}1.5 \pm 1.8 \\
(0 \sim 4)\end{array}$ & $\begin{array}{l}0.96 \pm 0.88 \\
(0 \sim 1.24)\end{array}$ \\
\hline
\end{tabular}

(A) 南湾水库

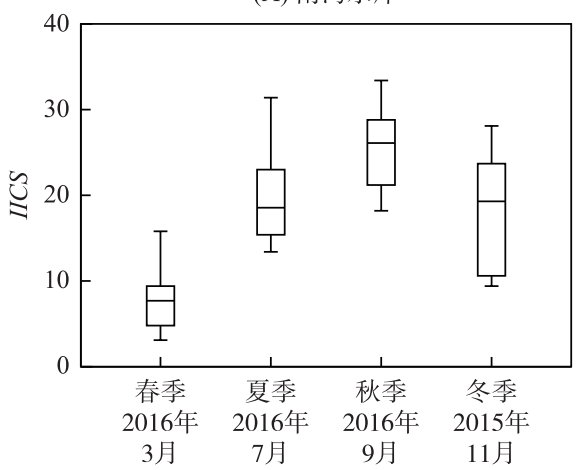

(B) 汤浦水库

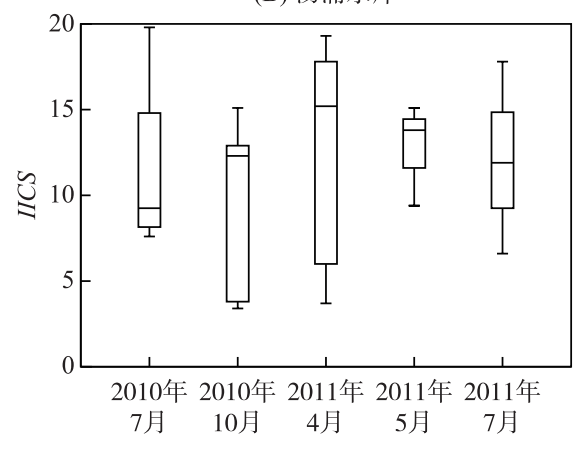

图 5 南湾水库和汤浦水库的 IICS 分值箱线图

(各水库 IICS 分值均为独立计算, 也即单个水库不同时期的数据归集在一起进行 IICS 分值计算)

Fig.5 The boxplots of IICS from Nanwan Reservoir and Tangpu Reservoir

因这些水体中不存在水温分层现象,水体底部不存在持续时间较长的厌氧环境,浮游生物在水体中基本均 匀分布, 可为底栖动物提供丰富的饵料来源, 从而有利于底栖动物群落的发展. 对于混合型水库而言, 随着 蓄水时间的延长, 水库底部沉积物会越来越多, 底栖动物现存量一般会呈现稳步增长的趋势 ${ }^{[47,65]}$. 如丹江口 水库是典型的混合型深水水库, 该水库不存在水温分层现象和较为严重的富营养化现象, 虽然其坝前水域 深达 $40 \mathrm{~m}$ 以上, 底栖动物密度仍然高达 $30000 \mathrm{ind} . / \mathrm{m}^{2}$ 以上 ${ }^{[66]}$. 相比较而言, 存在水温分层现象的南湾水库 和汤浦水库, 其底栖动物密度处于较低水平, 很大可能是富营养化带来的反向效应, 即富营养化程度的加重 导致水体底部 (温跃层以下) 厌氧环境的产生和缺氧程度的加剧, 浮游生物的趋避行为导致食物来源的缺 $\Sigma^{[58-61,67-68]}$, 这些因素共同限制了底栖动物的分布和种群规模的发展. 调查期间发现, 汤浦水库多个站位连 续多次未采集到任何底栖动物, 而南湾水库也有一个站位没有采集到任何样品, 且这些站位底泥多呈现炭 
黑色, 两座水库热分层期间底栖动物的单站物种数 和 Shannon-Wiener 指数均值明显低于其他时段, 这 可能是水库热分层和富营养化对底栖动物综合影响 效应的直接体现. 两个水库都有较长的水力滞留时 间以及持续较长时间的水温分层现象, 客观上造成 库区藻类水华在一定年份出现季节性暴发现

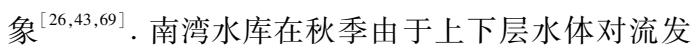
生混合, 溶解氧和营养物质相互补充, 暴发蓝藻水华 的概率较高, 而汤浦水库则由于硅藻所占比例较高, 在春季暴发硅藻水华的几率较高. 在水温分层现象 期间, 水库底部的缺氧或厌氧状态导致底栖动物多 样性和现存量处于较低水平, 分层现象结束后上下 水体的对流混合将下层沉积的营养物质带人上层, 客观上为藻类水华的暴发提供物质基础, 藻类暴发 后大量死亡的藻体沉人水底由于分解作用又加剧了 水温分层期间库底的缺氧程度, 从而导致底栖动物 遭受周期性的缺氧扰动, 其多样性和现存量难以得 以提高.
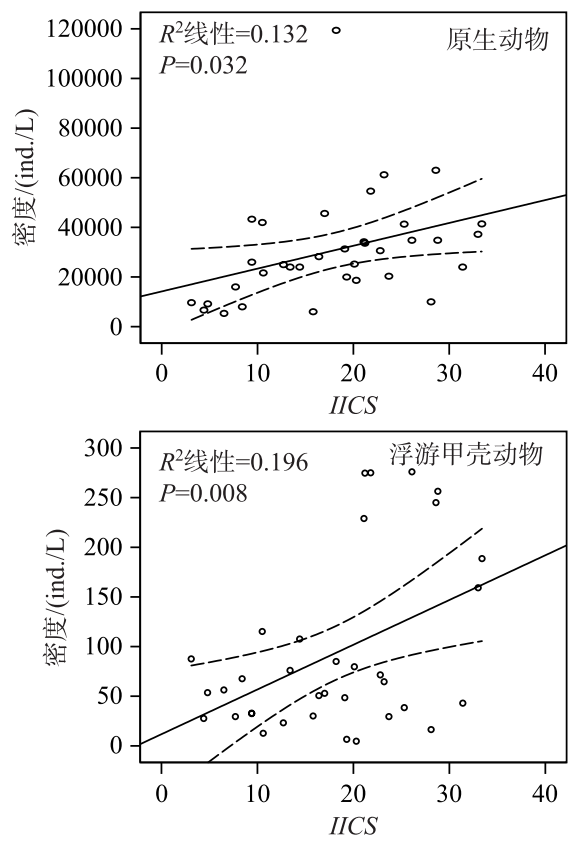

表 6 PLS 模型中潜在因子 1 解释的方差比例及 各变量在潜在因子 1 的权重 *

Tab.6 The explained proportions of variance from the latent factor 1 in the PLS models and the weights of different variable in the latent factor 1

\begin{tabular}{ccc}
\hline \multirow{2}{*}{ 变量 } & \multicolumn{2}{c}{ 潜在因子 1} \\
\cline { 2 - 3 } & 南湾水库 & 汤浦水库 \\
\hline$R_{\mathrm{X}^{2}}$ & 0.513 & 0.340 \\
$R_{\mathrm{Y}^{2}}$ & 0.275 & 0.249 \\
调整后的 $R^{2}$ & 0.253 & 0.202 \\
原生动物密度 & $\mathbf{0 . 4 9 4}$ & $\mathbf{- 0 . 8 5 9}$ \\
轮虫密度 & $\mathbf{0 . 2 9 1}$ & $\mathbf{- 0 . 4 1 1}$ \\
浮游甲壳动物密度 & $\mathbf{0 . 6 0 3}$ & 0.056 \\
浮游植物密度 & $\mathbf{0 . 5 5 5}$ & $\mathbf{- 0 . 2 9 9}$ \\
\hline
\end{tabular}

${ }^{*} R_{\mathrm{X} 2}$ 为模型中自变量解释的方差比例, $R_{\mathrm{Y}^{2}}$ 为模型中因 变量解释的方差比例, 权重绝对值大于 0.2 的变量粗 体显示,表示该变量很重要.
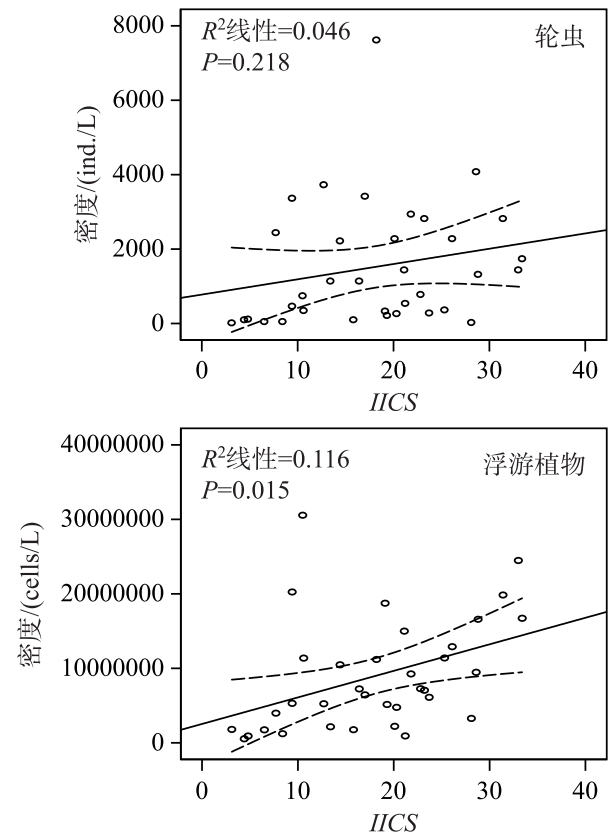

图 6 南湾水库中浮游生物密度与 $I I C S$ 的回归图

Fig.6 The regression charts of plankton density and IICS in Nanwan Reservoir

\section{3 底栖动物和浮游生物的关系}

研究表明, 在深水湖泊中浮游植物碎屑的沉积为底栖动物提供了可观的能量来源 ${ }^{[10]}$. 肠道物检测结果 表明, 糠虾 Mysis relicta 体内含有浮游植物以及浮游动物和轮虫残渣 ${ }^{[70]}$. 就一年尺度的观察结果而言, 瑞典 维内尔湖片脚类动物 Monoporeia affinis 的密度和春季硅藻的生物体有着非常重要的关系 ${ }^{[13,71]}$. 在湖泊和水 库生态系统中, 除了几种肉食性种类外, 深底带的绝大部分大型底栖动物种类与个体是杂食性的, 主要以细 

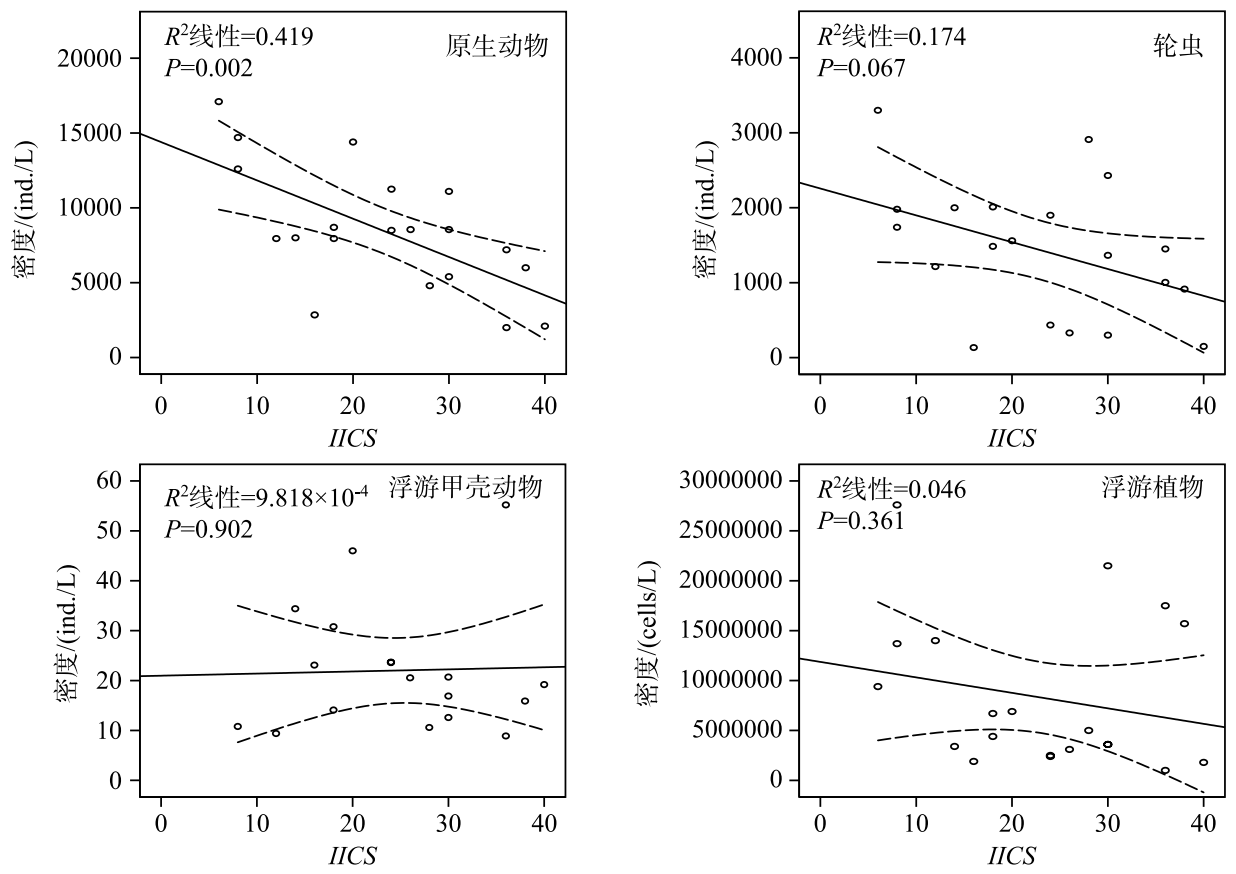

图 7 汤浦水库中浮游生物密度与 IICS 的回归图

Fig.7 The regression charts of plankton density and IICS in Tangpu Reservoir

菌包裹的碎屑颗粒及沉降到沉积物表面的藻类为食 ${ }^{[56]}$. 根据 PLS 模型的分析结果来看, 原生动物密度、轮 虫密度和浮游植物密度对南湾水库和汤浦水库的底栖动物群落状态均有重要影响, 是很好的预测变量, 但 预测的方向正好相反. 在南湾水库中, 原生动物、轮虫和浮游植物的密度上升伴随底栖动物群落状态的下 降, 也即这些浮游生物类群密度的升高不利于底栖动物群落的发展, 其可能的原因是富营养化导致浮游生 物的过度生长, 水温分层现象的形成也伴随着溶解氧分层的形成以及库底缺氧或厌氧状态的形成, 虽然浮 游生物丰度的升高客观上为底栖动物提供了可观的食物来源, 但由于底部生存环境的恶化, 底栖动物已不 能有效加以利用. 在汤浦水库中, 原生动物、轮虫和浮游植物的密度上升有助于底栖动物群落状态的提高, 也即这些浮游生物类群密度的增长有利于底栖动物群落的生长繁殖, 这符合在湖沼生态系统中浮游生物为 底栖动物提供旿料来源的预期 ${ }^{[72-73]}$, 同时也表明汤浦水库富营养化促进了浮游生物丰度发展, 虽然也存在 水温和溶解氧分层现象, 但浮游生物沉积的残渣能够为底栖动物充分利用, 其生存环境似乎要好于南湾水 库. 根据以上结果我们推断: 在水库还未进人以蓝藻占优势类群为表征的富营养化状态时, 浮游生物类群可 为底栖动物提供较为可观的食物来源, 其与底栖动物群落在食物链上存在较为紧密的正相关关系, 但当水 库已经进人以蓝藻占优势类群的富营养化状态时, 水体的高营养状态虽然促进了浮游生物类群的大发展, 但由于缺氧导致的生存环境恶化, 浮游生物与底栖动物在食物链上的联系不再紧密, 也即底栖动物已不能 有效地利用浮游生物提供的饵料来源, 反而由于大量浮游生物死亡残体的堆积造成的低氧或厌氧面积的扩 大导致种群发展受限. Spearman 秩相关分析和回归图分析结果也表明, 富营养化程度较轻的汤浦水库中, 浮 游生物类群中的原生动物、轮虫和浮游植物密度与底栖动物群落之间存在较强的正相关关系, 而富营养化 程度较重的南湾水库中, 浮游生物所有类群与底栖动物群落之间存在较强的负相关关系, 这与 PLS 模型的 分析结果可以相互印证.

根据以上分析可以看出, 营养化程度的加重会导致存在水温分层现象的水库中与沉积物接触的恒温层 存在严重的缺氧乃至厌氧现象, 同时浮游生物特别是浮游动物存在垂向迁移现象, 可以规避不利生境从而 向溶解氧和光照丰富的上层水体迁移 ${ }^{[11,67,73-74]}$, 导致水体底部浮游生物种群的匮乏, 而上层水体密度过大的 
藻类死亡后沉人水体底部在矿化分解过程中加速了溶解氧的消耗进而加重了水底的缺氧程度 ${ }^{[75-76]}$, 最终饵 料来源的缺乏以及厌氧环境的形成导致底栖动物种群的衰退. 总之,水库水温分层现象的存在对底栖动物 群落的发展是一大制约因素, 富营养化程度的加重可导致底栖动物种群的持续衰退, 底栖动物和浮游生物 的关系也会由相互促进的正相关关系转变为彼此制约的负相关关系. 而这种转变又与富营养化程度的加剧 导致的水底栖息环境的恶化和浮游生物对不利环境的趋避行为导致的食物匮乏有关. 当然这些推断需要更 多实证数据的支撑, 今后在富营养化水温分层水库中系统开展浮游生物的垂向分布与底栖动物群落及其分 布关系的研究很有必要. 如果这一推论得到更多野外数据的支撑, 则今后可通过探讨浮游生物和底栖动物 群落的关系来推证水库的富营养化程度, 从而为水库管理方提供更多有价值的参考信息,进而采取必要措 施保护和改善水库生态环境.

致谢: 感谢水利部中国科学院水工程生态研究所的李嗣新、张俊芳、陈威同志对野外工作的帮助. 感谢河南 省南湾水库管理局和浙江省绍兴市汤浦水库有限公司的同志予以的大力支持与配合.

\section{4 参考文献}

[ 1 ] Chi SY, Yu JJ, Hui C et al. Study on the development of a biological Integrity Index based on zoobenthos for drinking water resources-based reservoirs. Journal of Hydroecology, 2012, 33(2): 6-15. [池仕运, 俞建军, 陈晖等. 供水型水库底 栖动物完整性指数的构建. 水生态学杂志, 2012, 33(2): 6-15.]

[ 2 ] Han BP. Reservoir ecology and limnology in China: a retrospective comment. J Lake Sci, 2010, 22(2) : 151-160. DOI: 10.18307/2010.0201. [韩博平. 中国水库生态学研究的回顾与展望. 湖泊科学, 2010, 22(2) : 151-160.]

[ 3 ] Wang Y, Dai HC. Effects of water temperature delamination in large-scale reserviors and protection methods. Journal of China Three Gorges University, 2009, 31(6): 11-14. [王显, 戴会超. 大型水库水温分层影响及防治措施. 三峡大学 学报: 自然科学版, 2009, 31(6): 11-14.]

[ 4 ] Qiu XP, Huang YL, Zeng MZ. Responses of dissolved oxygen on thermal stratification and eutrophication in lakes and reservoirs-An example in Zhoucun Reservoir in Zaozhuang City. China Environmental Science, 2016, 36 (5) : 1547-1553. [邱晓鹏, 黄廷林, 曾明正. 溶解氧对湖库热分层和富营养化的响应一以㫫庄周村水库为例. 中国环境科学, 2016, 36(5) : 1547-1553.]

[ 5 ] Chi SY, Wei CZ, Hu J et al. Preliminary study of macroinvertebrate communities in Nanwan Reservoir. Environmental Protection Science, 2018, 44(6):34-41. [池仕运, 韦翠珍, 胡俊等. 南湾水库底栖动物群落结构初步研究. 环境保护 科学, $2018,44(6): 34-41$. ]

[ 6 ] Utete B, Zenda S, Mbauya WA et al. Plankton and macroinvertebrate community composition in the pelagic and non-vegetated littoral drawdown zones of a shallow reservoir, Manjirenji, Zimbabwe. Applied Ecology \& Environmental Research, 2017, 15(1) : 743-766.

[ 7 ] Kozak A, Gołdyn R. Zooplankton versus phyto- and bacterioplankton in the Maltański Reservoir (Poland) during an extensive biomanipulation experiment. Journal of Plankton Research, 2004, 26(1) : 37-48.

[ 8 ] Zimmer KD, Hanson MA, Butler MG et al. Size distribution of aquatic invertebrates in two prairie wetlands, with and without fish, with implications for community production. Freshwater Biology, 2001, 46(10): 1373-1386.

[ 9 ] Vaughn CC, Hakenkamp CC. The functional role of burrowing bivalves in freshwater ecosystems. Freshwater Biology, 2001, 46(11): 1431-1446.

[10] Sierszen ME, Peterson GS, Scharold JV. Depth-specific patterns in benthic planktonic food web relationships in Lake Superior. Canadian Journal of Fisheries Aquatic Sciences, 2006, 63(7) : 1496-1503.

[11] Bowers JA, Vanderploeg HA. In situ predatory behavior of Mysis relicta in Lake Michigan. Hydrobiologia, 1982, 93(1): 121-131.

[12] Goedkoop W, Johnson RK. Pelagic-benthic coupling: Profundal benthic community response to spring diatom deposition in mesotrophic Lake Erken. Limnology and Oceanography, 1996, 41(4) : 636-647.

[13] Johnson RK, Wiederholm T. Pelagic-benthic coupling-The importance of diatom interannual variability for population oscillations of Monoporeia affinis. Limnology and Oceanography, 1992, 37(8) : 1596-1607.

[14] Liu XQ, Wang HZ, Liang XM. Food web of macroinvertebrate community in a Yangtze shallow lake: trophic basis and pathways. Hydrobiologia, 2006, 571 ( 1 ) : 283-295. 
[15] Vadeboncoeur Y, Lodge DM. Putting the lake back together: Reintegrating benthic pathways into lake food web models. Bioscience, 2002, 52(1): 44-54.

[16] Dong SL, Wang LZ, Shi WL. Investigation on fishery biolog of Qinhe Reservoir. Journal of Dalian Fisheries University, 1986, 6(6) : 45-56. [董双林, 王立柱, 史为良. 清河水库渔业生物学调查. 大连海洋大学学报, 1986, 6 (6): 45-56. ]

[17] Peng JH. The crustacean zooplankton in the Danjiangkou Reservoir. J Lake Sci, 1995, 7(3) : 240-248. DOI: 10.18307/ 1995.0306. [彭建华. 丹江口水库的浮游甲壳动物. 湖泊科学, 1995, 7(3) : 240-248.]

[18] Yang G, Yang GR, Liu JL. Plankton resource survey of Danjiangkou Reservoir. Journal of Hubei Agricultural College, 1996, 16(1) : 38-42. [杨广, 杨干荣, 刘金兰. 丹江口水库浮游生物资源调查. 湖北农学院学报, 1996, (1): 38-42.]

[19] Shen XY. Investigation report on water quality of Nanwan Reservoir in Xinyang. Henan Fisheries, 2004, 58(1) : 19-20. [申秀英. 信阳南湾水库水质调查报告. 河南水产, 2004, 58(1): 19-20.]

[20] Yu G. Analysis of water quality and eutrophication characteristics of Nanwan Reservoir. Henan Water Resources \& South-toNorth Water Diversion, 2013, (4) : 3-4. [于刚. 南湾水库水质及富营养化特征分析. 河南水利与南水北调, 2013, (4) : 3-4.]

[21] Zhu JK, Yu HP, Shi LD et al. Research and explore of water eutrophic in Tangpu reservoir. Environmental Science \& Tech$n o l o g y, 2010,33(6 \mathrm{E}): 219-221$. [ 朱建坤, 俞海平, 施练东等. 汤浦水库富营养化趋势分析及防治研究. 环境科学 与技术, $2010,33(6 \mathrm{E}): 219-221$.]

[22] Chen XM, Zhang HZ, Zou FJ et al. Effects of the regionally economical structure on water qualities of large reservoirs-a case study in Nanwan Reservoir of Xinyang of China. Journal of Shangqiu Teachers College, 2009, 25(9): 119-122. [ 陈 向明, 张海震, 邹法俊等. 水库区域经济结构对水库水质的影响分析一以河南省信阳市南湾水库为例. 商丘师 范学院学报, 2009, 25(9): 119-122.]

[23] Li XY, Zhu FR, Zhang SH et al. Plankton and Microcystis culture in Nanwan Reservoir and Baiguishan Reservoir. Henan Fisheries, 2003, (2) : 29-30. [李效宇, 朱风荣, 张素华等. 南湾水库和白龟山水库的浮游生物及微囊藻的培养. 河南水产, 2003, (2) : 29-30.]

[24] Xin XY. Preliminary study on the population structure and water pollution assessment of phytoplanktonic diatoms in Nanwan Reservoir, Henan Province. Chinese Journal of Ecology, 2003, 22(5) : 125-126. [辛晓云. 河南南湾水库浮游硅 藻的种群结构与水质污染评价初步研究. 生态学杂志, 2003, 22(5): 125-126.]

[25] Bai LL. Analysis of water resources characteristics of Nanwan Reservoir. Henan Water Resources \& South-to-North Water Diversion, 2004, (5) : 16. [白林龙. 南湾水库水资源特性分析. 河南水利与南水北调杂志, 2004, (5): 16.]

[26] Zhou XY, Shen Y, Cai HJ et al. Study on water quality of Tangpu Reservoir for drinking water supply in Shaoxing City. Water \& Wastewater Engineering, 2008, 4(1):38-42. [周晓燕, 沈雁, 蔡海江等. 绍兴市饮用水源汤浦水库水质特 征研究. 给水排水, 2008, 34(1): 38-42.]

[27] Editorial Board of Water and Wastewater Monitoring and Analysis Methods, Ministry of Environmental Protection of the People's Republic of China eds. Water and Wastewater Monitoring and Analysis Methods: 4th edition. Beijing: China Environmental Science Press, 2002. [ 国家环境保护总局《水和废水监测分析方法》编委会. 水和废水监测分析方法: 第 4 版. 北京: 中国环境科学出版社, 2002.]

[28] Morse JC, Yang L, Tian L eds. Aquatic insects of China useful for monitoring water quality (5.1st Edition). Nanjing: Hohai University Press, 1994.

[29] Wang HZ ed. Studies on taxonomy, distribution and ecology of microdrile oligochaetes of China, with descriptions of two new species from the vicinity of the great wall station of china, antarctica. Beijing: Higher Education Press, 2002. [王洪 铸. 中国小蚓类研究——附中国南极长城站附近地区两新种. 北京: 高等教育出版社, 2002.]

[30] Hu HJ, Wei YX eds. Freshwater algae in China-Systematics, classification and ecology. Beijing: Science Press, 2006. [胡鸿钧, 魏印心. 中国淡水藻类——系统、分类及生态. 北京: 科学出版社, 2006.]

[31] Zhang ZS, Huang XF eds. Research methods of freshwater plankton. Beijing: Science Press, 1991. [章宗涉, 黄祥飞. 淡 水浮游生物研究方法. 北京: 科学出版社, 1991.]

[32] Shen YF, Zhang ZS, Gong XJ eds. New technology of micro-biological monitoring. Beijing: China Construction Industry Press, 1990. [ 沈暳芬,章宗涉,龚循矩. 微型生物监测新技术. 北京: 中国建筑工业出版社, 1990.] 
[33] Shen JR ed. Fauna Sinica一Freshwater Copepods. Beijing: Science Press, 1979. [沈嘉瑞. 中国动物志一一节肢动物门 甲壳纲 淡水桡足类. 北京: 科学出版社, 1979.]

[34] Jiang XZ, Du NS eds. Fauna Sinica一Freshwater Cladocera. Beijing: Science Press, 1979. [蒋潡治, 堵南山. 中国动物 志一一节肢动物门甲壳纲 淡水枝角类. 北京: 科学出版社, 1979. ]

[35] Hu J, Gong C, Xia W et al. Study on phytoplankton community structure and its relationship with environmental factors in tian’e section, Changjiang River. Oceanologia et Limnologia Sinica, 2018, 49(1): 70-77. [胡俊, 龚成, 夏纬等. 天鹅洲 长江段浮游植物群落季节演替及环境因子研究. 海洋与湖沼, 2018, 49(1) : 70-77.]

[36] Bakanov A. Present-day state of zoobenthos in the upper volga reservoirs. Water Resources, 2003, 30(5) : 559-568.

[37] Malmqvist B, Hoffsten PO. Influence of drainage from old mine deposits on benthic macroinvertebrate communities in central Swedish streams. Water Research, 1999, 33(98) : 2415-2423.

[38] Redfield AC. The biological control of chemical factors in the environment. Science Progress, 1958, 11(11): 150-170.

[39] Chen FY, Jia CH, Sun CQ et al. Study on the pollution of planktonic algae in the drinking water source reserve of Nanwan Reservoir and its prevention and control strategies. Journal of Jiaozuo Teachers College, 2010, 26(4) : 74-77. [ 陈飞燕, 贾昌虎, 孙朝琴等. 南湾水库饮用水源保护区浮游藻类污染及其防控对策研究. 焦作师范高等专科学校学报, 2010, 26(4): 74-77.]

[40] Bao BZ, Meng YZ, Xia F et al. Preliminary study on algae toxin pollution of drinking water sources in Henan Province. Henan Journal of Preventive Medicine, 1999, 10(3) : 168-169. [鲍宝珠, 孟玉珍, 夏方等. 河南省生活饮用水源藻类 毒素污染的初探. 河南预防医学杂志, 1999, (3) : 168-169.]

[41] Li LC. Study on current state and fish culture manipulation on Nanwan Reservoir eutrophication [ Dissertation]. Wuhan: Huazhong Agricultural University, 2007. [李林春. 南湾水库富营养化现状与养鱼调控的研究 [学位论文]. 武汉: 华 中农业大学, 2007.]

[42] Ma PM, Shi LD, Zhao XF et al. A bloom-forming freshwater diatom: Achnanthidium catenatum. J Lake Sci, 2013,25 (1) : 156-162. DOI: 10.18307/2013.0120. [马沛明, 施练东, 赵先富等. 一种淡水水华硅藻一一链状弯壳藻 (Achnanthidiu mcatenatum). 湖泊科学, 2013, 25(1) : 156-162.]

[43] Shi LD, Zhu WJ, Zhang JF et al. Seasonal succession of phytoplankton community structures and analysis of spring water bloom in subtropical reservoir-As Tangpu Resevior in Zhejiang Province. Journal of Hydroecology, 2013, 34(2) : 32-39. [施练东, 竺维佳, 张俊芳等. 亚热带水库浮游植物群落结构季节演替及其春季水华成因分析一一以浙江汤浦水 库为例. 水生态学杂志, 2013, 34(2): 32-39.]

[44] Ma PM, Shi LD, Zhang JF et al. Succession of phytoplankton assemblages and its influencing factors in Tangpu Trservoir, Zhejiang Province. Environmental Science, 2016, 37(12) : 4560-4569. [马沛明, 施练东, 张俊芳等. 浙江汤浦水库浮 游植物季节演替及其影响因子分析. 环境科学, 2016, 37(12) : 4560-4569.]

[45] Iwakuma T. Emergence of Chironomidae from the shallow eutrophic Lake Kasumigaura, Japan. Hydrobiologia, 1992, 245 (1) : 27-40.

[46] Yu ZM, Wang R, Shen XD et al. Investigation on the role of population ecology of Tokunagayusurika akamusi ( Tokunaga) in nitrogen and phosphorus cycle in West Lake. Environmental Pollution Control, 1997, 19(1): 28-31. [虞左明, 王锐, 沈小东等. 大红德永摇蚊种群生态在西湖氮磷循环中作用的调查研究. 环境污染与防治, 1997, 19(1): 28-31.]

[47] Ma XF, Xiong BX, Wang MX et al. The community structure and biodiversity of macrozoobenthos in Daoguanhe Reservoir, Hubei Province. J Lake Sci, 2004, 16(1) : 49-55. DOI: 10.18307/2004.0107. [马徐发, 熊邦喜, 王明学等. 湖北道 观河水库大型底栖动物的群落结构及物种多样性. 湖泊科学, 2004, 16(1) : 49-55.]

[48] Qiu CG, Zhao W, Chen LB et al. Community structure and spatial-temporal pattern of zoobenthos in Tanghe Reservoir, Liaoning Province, China. Journal of Dalian Fisheries University, 2009, 24(E) : 107-112. [邱春刚, 赵文, 陈立斌等. 汤 河水库底栖动物的群落结构及时空格局的研究. 大连水产学院学报, 2009, 24(增刊) : 107-112.]

[49] Chen LB, Zhao W, Yin SR et al. Community structure and spatio-temporal pattern of zoobenthos in Guanting Reservoir, Beijing, China. Journal of Dalian Ocean University, 2012, 27(1):44-52. [ 陈立斌, 赵文, 殷守仁等. 官厅水库底栖 动物的群落结构及其时空格局. 大连海洋大学学报, 2012, 27(1) : 44-52.]

[50] Dai LQ, Li H, Chen XY. Study on water temperature structure and its impact on water quality at reservoir area. Hongshui River, 2010, 29(5) : 30-35. [ 戴凌全, 李华, 陈小燕. 水库水温结构及其对库区水质影响研究. 红水河, 2010, 29 (5) : 30-35.] 
[51] White DS. The benthic macroinvertebrates of Kentucky Lake, a Mainstem Reservoir on the Tennessee River, U.S.A. Transactions of the American Entomological Society, 2014, 140(1) : 83-99.

[52] Casellato S, Caneva F. Composition and distribution of bottom oligochaete fauna of a north Italian eutrophic lake (Lake Ledro). Hydrobiologia, 1994, 278(1): 87-92.

[53] Diaz RJ. Marine benthic hypoxia, a review of its ecological effects and the behavioral responses of benthic macrofauna. Oceanogr Mar Biol Annu Rev, 1995, 33: 245-303.

[54] Camargo JA, Alonso Á. Ecological and toxicological effects of inorganic nitrogen pollution in aquatic ecosystems: A global assessment. Environment International, 2006, 32(6) : 831-849.

[55] Dumnicka E, Galas J. Distribution of benthic fauna in relation to environmental conditions in an inundated opencast sulphur mine (Piaseczno Reservoir, Southern Poland). Aquatic Ecology, 2006, 40(2) : 203-210.

[56] Kalff J ed. Limnology一inland water ecosystems. Beijing: Higher Education Press, 2011. [Kalff J. 湖沼学: 内陆水生态 系统. 北京: 高等教育出版社, 2011.]

[57] He T. Investigation on present situation of fishery resources and their development and utilization in Nanwan Reservoir, Henan Province[Dissertation]. Wuhan: Huazhong Agricultural University, 2006. [何涛. 河南省南湾水库渔业资源现 状调查及开发利用研究 [学位论文]. 武汉:华中农业大学, 2006.]

[58] Roman MR, Kimmel DG, Boicourt WC et al. Impacts of hypoxia on zooplankton spatial distributions in the northern gulf of Mexico. Estuaries \& Coasts, 2012, 35(5) : 1261-1269.

[59] Vad CF, Horváth Z, Kiss KT et al. Vertical distribution of zooplankton in a shallow peatland pond: the limiting role of dissolved oxygen. Ann Limnol - Int J Lim, 2013, 49(4) : 275-285.

[60] Geller W. Diurnal vertical migration of zooplankton in a temperate great lake ( L. Constance): A starvation avoidance mechanism? Archiv fuir Hydrobiologie, 1986, 74(Supplement 1) : 1-60.

[61] Niu Y, Kong XH, Yu H et al. Spatial distribution of phytoplankton community during summer stratification in Lake Fuxian. Chinese Journal of Ecology, 2016, 35(7): 1865-1871. [牛远, 孔祥虹, 余辉等. 抚仙湖夏季热分层时期浮游植 物空间分布特征. 生态学杂志, 2016, 35(7) : 1865-1871.]

[62] Gong ZJ, Xie P, Tang HJ et al. The influence of eutrophycation upon community structure and biodiversity of macrozoobenthos. Acta Hydrobiologica Sinica, 2001, 25(3) : 210-216. [龚志军, 谢平, 唐汇涓等. 水体富营养化对大型底栖动 物群落结构及多样性的影响. 水生生物学报, 2001, 25(3): 210-216.]

[63] Wang YD, Xiong BX, Yang XF. Coumunity structure of macrozoobenthos in Lake Nanhu, Wuhan, China. J Lake Sci, 2005, 17(4) : 327-333. DOI: 10.18307/2005.0408. [王银东, 熊邦喜, 杨学芬. 武汉市南湖大型底栖动物的群落结 构. 湖泊科学, $2005,17(4): 327-333$. ]

[64] Wu GZ, Li CY. Investigation of zooplankton and zoobenthos in Lake Wuliangsuhai, Inner Mongolia. J Lake Sci, 2008, 20 (4) : 538-543. DOI: 10.18307/2008.0419. [武国正, 李畅游. 内蒙古乌梁素海浮游动物与底栖动物调查. 湖泊科 学, 2008, 20(4): 538-543.]

[65] Lv GJ, Xiong BX, Liu M et al. The community structure of macrozoobenthos and water quality assessment on different trophic types of reservoirs. Acta Ecologica Sinica, 2009, 29(10): 5339-5349. [吕光俊, 熊邦喜, 刘敏等. 不同营养类 型水库大型底栖动物的群落结构特征及其水质评价. 生态学报, 2009, 29(10): 5339-5349.]

[66] Zhang M, Shao ML, Cai QH et al. Macroinvertebrate community structure and the biological assessment to the water quality of the Danjiangkou Reservoir. J Lake Sci, 2010, 22(2) : 281-290. DOI: 10.18307/2010.0219. [张敏, 邵美玲, 蔡庆 华等. 丹江口水库大型底栖动物群落结构及其水质生物学评价. 湖泊科学, 2010, 22(2) : 281-290.]

[67] Lin J, Su YP, Zhong HZ et al. Vertical distribution of phytoplankton in a eutrophic reservoir, Shanzi Reservoir( Fujian) during summer stratification. J Lake Sci, 2010, 22(2) : 244-250. DOI: 10.18307/2010.0214. [林佳, 苏玉萍, 钟厚璋 等.一座富营养化水库——福建山仔水库夏季热分层期间浮游植物垂向分布. 湖泊科学, 2010, 22(2) : 244-250.]

[68] Kuczyńska-Kippen N. Diel vertical distribution of zooplankton in Piaseczno Lake (Wda Landscape Park) - I . crustacea. Oceanological \& Hydrobiological Studies, 2005, 34(4) : 97-108.

[69] Shi LD, Yu HP, Zhu JK et al. SWAT-based simulation on non-point source pollution in the Tangpu Reservoir Basin. Journal of Hydroecology, 2011, 32(3) : 66-70. [施练东, 俞海平, 朱建坤等. 基于 SWAT 模型的汤浦水库流域非点源污 染模拟. 水生态学杂志, 2011, 32(3): 66-70.]

[70] Johannsson OE, Leggett MF, Rudstam LG et al. Diet of Mysis relicta in Lake Ontario as revealed by stable isotope and gut 
content analysis. Canadian Journal of Fisheries and Aquatic Sciences, 2001, 58(10) : 1975-1986.

[71] Goedkoop W, Johnson RK. Factors affecting population fluctuations of the glacial relict amphipod Monoporeia affinis (Lindström) in Sweden's largest lakes. Ambio, 2001, 30(8) : 552-558.

[72] Wang HZ, Xu QQ, Cui YD et al. Macrozoobenthic community of Poyang Lake, the largest freshwater lake of China, in the Yangtze floodplain. Limnology, 2007, 8(1): 65-71.

[73] Macphee SA, Arnott SE, Keller W. Lake thermal structure influences macroinvertebrate predation on crustacean zooplankton. Journal of Plankton Research, 2011, 33(10) : 1586-1595.

[74] Pinel-Alloul1 B, Méthot G, Malinsky-Rushansky NZ. A short-term study of vertical and horizontal distribution of zooplankton during thermal stratification in Lake Kinneret, Israel. Hydrobiologia, 2004, 526(1) : 85-98.

[75] Qin BQ, Gao G, Zhu GW et al. Lake eutrophication and its ecosystem response. Chinese Science Bulletin, 2013, 58( 10) : 855-864. [ 秦伯强, 高光, 朱广伟等. 湖泊富营养化及其生态系统响应. 科学通报, 2013, 58(10): 855-864.]

[76] Lu JS, Li ZL. Seasonal effects of thermal stratification on the water quality of deep reservoirs: a case study of heihe reservoir, Xian city. J Lake Sci, 2014, 26(5)：698-706. DOI: 10.18307/2014.0507. [卢金锁, 李志龙. 热分层对水库水 质的季节性影响——西安黑河水库为例. 湖泊科学, 2014, 26(5): 698-706.] 